Short Note

\title{
(E)-3-((2-Fluorophenyl)(hydroxy)methylene)imidazo[1,2- a]pyridin-2(3H)-one
}

\author{
Giammarco Tenti, Ángel Cores, María Teresa Ramos $[$ and J. Carlos Menéndez *
}

check for updates

Citation: Tenti, G.; Cores, Á.; Ramos, M.T.; Menéndez, J.C. (E)-3-((2Fluorophenyl)(hydroxy)methylene)imidazo[1,2-a]pyridin-2(3H)-one. Molbank 2021, 2021, 0.

https: / / doi.org/

Academic Editors: Dimitrios Matiadis and Eleftherios Halevas

Received: 28 April 2021

Accepted: 8 May 2021

Published: 14 May 2021

Publisher's Note: MDPI stays neutral with regard to jurisdictional claims in published maps and institutional affiliations.

Copyright: () 2021 by the authors. Licensee MDPI, Basel, Switzerland. This article is an open access article distributed under the terms and conditions of the Creative Commons Attribution (CC BY) license (https:// creativecommons.org/licenses/by/ $4.0 /)$.
Unidad de Química Orgánica y Farmacéutica, Departamento de Química en Ciencias Farmacéuticas, Facultad de Farmacia, Universidad Complutense, 28040 Madrid, Spain; giammarco.tenti@hotmail.it (G.T.); acores@ucm.es (Á.C.); mtramos@ucm.es (M.T.R.)

* Correspondence: josecm@ucm.es; Tel.: +(34)-91-3941840

Abstract: Treatment of a N-2-pyridyl- $\beta$-ketoamide precursor with bromine afforded the first example of the 3-aryl( $\alpha$-hydroxy)methylenelimidazo[1,2-a]pyridin-2(3H)-one framework. This transformation proceeded through a domino process comprising an initial bromination, cyclization via an intramolecular $S_{N}$ reaction, and a final keto-enol tautomerism, and allows generation of the fused heterocyclic system and installation of the acyl substituent in a single operation.

Keywords: nitrogen heterocycles; domino reactions; bromination; intramolecular $\mathrm{S}_{\mathrm{N}}$ displacement

\section{Introduction}

Fused heterocyclic compounds bearing bridgehead nitrogen atoms are very relevant in the construction of diversity-oriented libraries. Imidazo[1,2-a]pyridine is one of these frameworks, and has shown great promise in the treatment of cancer due to the ability of many of its derivatives to inhibit a variety of kinases [1,2]. Moreover, several drugs currently in the market contain an imidazo[1,2-a]pyridine core, including the hypnotic zolpidem [3], the anxyolitic alpidem [4], the gastroprotective drug zolimidine [5], and the cardiotonic olprinone [6] (Figure 1). The importance of this ring system has led to much interest in its synthesis [7] and functionalization [8]. Imidazo[1,2-a]pyridin-2(3H)one, one of its derivatives, is less well-known but has nevertheless shown some relevant pharmacological activities [9].

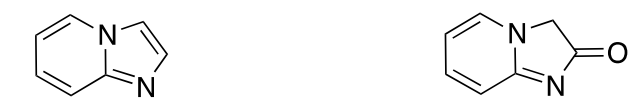

Imidazo[1,2-a]pyridine

Imidazo[1,2-a]pyridin-2(3H)-one<smiles>[R7]C(=O)Cc1c(-c2ccc([R])cc2)nc2ccc([R7])cn12</smiles>

Zolpidem: $\mathrm{R}^{1}=\mathrm{R}^{2}=\mathrm{R}^{3}=\mathrm{Me}$, Alpidem: $\mathrm{R}^{1}=\mathrm{R}^{3}=\mathrm{Cl} ; \mathrm{R}^{2}=\mathrm{Pr}$<smiles>COS(=O)(=O)c1ccc(-c2cn3ccccc3n2)cc1</smiles>

Zolimidine<smiles>Cc1[nH]c(=O)c(C#N)cc1-c1ccc2nccn2c1</smiles>

Olprinone
Figure 1. Structures of imidazo[1,2-a]pyridine, imidazo[1,2-a]pyridin-2(3H)-one and some relevant imidazo[1,2-a]pyridines.

In spite of the potential importance of the imidazo[1,2-a]pyridin-2(3H)-one framework, some of its derivatives have not been accessible to date. In particular, 3-acyl derivatives have been prepared only in one occasion, by acylation of an imidazo[1,2-a]pyridin-1-ium substrate (Scheme 1) [10]. This method yields compounds in mesoionic form, which was 
suitable for the purpose of the researchers, who aimed at the discovery of mesoionic nicotinic acetylcholine antagonists acting as insecticides [11], but it lacks generality.

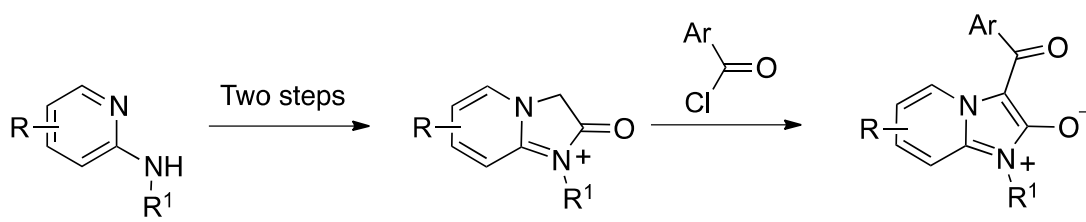

Scheme 1. Precedent for the synthesis of mesoionic 3-acyl-imidazo[3,2-a]pyridinium derivatives.

In this context, we describe here the synthesis of a representative of the 3-acylimidazo$[1,2-a]$ pyridin-2(3H)-one class of compounds from very simple starting materials and catalysts, using as the key step a domino reaction that generates the fused heterocyclic system and installs the acyl substituent in a single operation.

\section{Results and Discussion}

The synthesis of our target compound 5 is summarized in Scheme 2. The starting material 1, a derivative of ethyl 3-oxo-3-phenylpropanoate, was treated with 2-aminopyridine in refluxing toluene containing acetic acid as catalyst to yield the $\beta$-ketoamide 3 . Its halogenation with bromine in dichloromethane afforded 5 via a domino sequence of reactions that comprised the initial halogenation of $\mathbf{3}$ at its central carbon, followed by cyclization by intramolecular $\mathrm{S}_{\mathrm{N}} 2$ displacement of bromide anion and a final keto-enol tautomerism.<smiles>CCOC(=O)CC(=O)c1ccccc1F</smiles><smiles>CC(C)CC1=NC(=O)C(O)=C1c1ccccc1F</smiles><smiles>O=C1N=C2C=CC=CN2C1C(=O)c1ccccc1F</smiles><smiles>CC(C)(C)C1(C)CCCCC1</smiles><smiles>O=C(CC(=O)c1ccccc1F)Nc1ccccn1</smiles><smiles>O=C(Nc1ccccc1)C(Br)(Br)C(=O)c1ccccc1F</smiles>

Scheme 2. Synthesis of compound 5.

The enol structure of the imidazo[1,2-a]pyridin-2(3H)-one derivative 5 was established by the absence of signals ascribable to a proton neighboring two carbonyls or its corresponding carbon and also to a ketone carbonyl, all of which would be expected from a dicarbonyl structure. On the other hand, an enol proton was observed at $12.28 \mathrm{ppm}$, and the presence of quaternary carbons at 104.7 (C-3) and $175.3 \mathrm{ppm}(\mathrm{C}-\alpha)$, which showed a correlation with $\mathrm{H}-6^{\prime}$ in the HMBC experiment, also support the enol tautomeric form. The alternative lactim tautomer was discarded because of the absence of a ketone carbonyl at ca. $190 \mathrm{ppm}$. The presence of a doublet at ca. $9.9 \mathrm{ppm}$ with coupling constant $7 \mathrm{~Hz}$, assigned to $\mathrm{H}-5$, can be ascribed to the influence of the diamagnetic anisotropy cone of the arylmethylene substituent on the $\mathrm{H}-5$ proton, and confirms the $(E)$ configuration of the double bond. The assignment of the ${ }^{1} \mathrm{H}$ - and ${ }^{13} \mathrm{C}-\mathrm{NMR}$ data was aided by the ${ }^{19} \mathrm{~F}-{ }^{13} \mathrm{C}$ couplings, which allowed the unequivocal identification of the fluorophenyl ring carbons and also of the corresponding protons via H-C correlation 2D-NMR experiments (Supplementary Materials). Because H-5 had been assigned as described above, 2D-NMR data also enabled identification of the signals due to the $\mathrm{H}$ and $\mathrm{C}$ atoms at the 5, 6, 7, 8, and $8 \mathrm{a}$ positions. Copies of NMR spectra can be found in the Supporting Information. 


\section{Materials and Methods}

General experimental information. All reagents (Sigma-Aldrich, Madrid, Spain; Fischer Chemical, Madrid, Spain; Alpha Aesar, Kändel, Germany) and solvents (Scharlau, Barcelona, Spain; Fischer Chemical, Madrid, Spain) were of commercial quality and were used as received. Reactions were monitored by thin layer chromatography on aluminum plates coated with silica gel and fluorescent indicator (Merck, Madrid, Spain) acherey-Nagel Xtra SIL G/UV254. Melting points were determined using a Stuart Scientific apparatus, SMP3 Model, and are uncorrected. Infrared spectra were recorded with an Agilent Cary630 FTIR spectrophotometer (Madrid, Spain) working by attenuated total reflection (ATR), with a diamond accessory for solid and liquid samples. NMR spectroscopic data were recorded using a Bruker Avance 250 spectrometer (Rivas-Vaciamadrid, Spain) operating at $250 \mathrm{MHz}$ for ${ }^{1} \mathrm{H}-\mathrm{NMR}$ and $63 \mathrm{MHz}$ for ${ }^{13} \mathrm{C}-\mathrm{NMR}$ maintained by the NMR facility of Universidad Complutense (CAI de Resonancia Magnética Nuclear, Madrid, Spain); chemical shifts are given in ppm and coupling constants in Hertz. ${ }^{1} \mathrm{H}$ - and ${ }^{13} \mathrm{C}-\mathrm{NMR}$ assignments were supported by 2D-NMR experiments and are in agreement with simulations performed with MestreNova and ChemDraw Pro. Elemental analyses were determined by the microanalysis facility of Universidad Complutense (CAI de Microanálisis Elemental, Madrid, Spain), using a Leco 932 combustion microanalyzer.

3-(2-Fluorophenyl)-3-oxo- $N$-(pyridin-2-yl)propanamide (3). A solution of ethyl 3-(2fluorophenyl)-3-oxopropanoate (631 mg, $3.0 \mathrm{mmol})$, 2-aminopyridine ( $310 \mathrm{mg}, 3.3 \mathrm{mmol})$, and glacial acetic acid $(0.3 \mathrm{~mL})$ in toluene $(7.5 \mathrm{~mL})$ was heated under reflux with a DeanStark trap for $12 \mathrm{~h}$. After completion of the reaction (checked by TLC), the solvent was evaporated under reduced pressure and the crude residue was purified by crystallization from ethyl ether giving 3 as a yellow solid $(745 \mathrm{mg}, 96 \%)$ comprised of a mixture of the $\beta$-ketoamide and its tautomeric enol form in a ratio of 1.4:1. MP: $142{ }^{\circ} \mathrm{C}$. ${ }^{1} \mathrm{H}-\mathrm{NMR}$ (250 MHz, DMSO-d 6 ) $\delta 14.39$ (s, $1 \mathrm{H}$, enol), 10.88 (s, $1 \mathrm{H}$, enol), 10.71 (s, $1 \mathrm{H}, \beta$-ketoamide), 8.38-8.28 ( $\mathrm{m}, 1 \mathrm{H}$, enol + $\beta$-ketoamide), $8.14-8.02(\mathrm{~m}, 1 \mathrm{H}$, enol + $\beta$-ketoamide), 7.93-7.50 $(\mathrm{m}, 3 \mathrm{H}$, enol $+\beta$-ketoamide $), 7.44-7.29(\mathrm{~m}, 2 \mathrm{H}$, enol $+\beta$-ketoamide $), 7.12(\mathrm{~m}, 1 \mathrm{H}$, enol + $\beta$-ketoamide), $6.27\left(\mathrm{~s}, 1 \mathrm{H}\right.$, enol), $4.16\left(\mathrm{~s}, 2 \mathrm{H}, \beta\right.$-ketoamide) ppm. ${ }^{13} \mathrm{C}-\mathrm{NMR}(63 \mathrm{MHz}$, DMSO- $\left.\mathrm{d}_{6}\right) \delta 192.13\left(\mathrm{C}_{\mathrm{q}}\right), 192.08\left(\mathrm{C}_{\mathrm{q}}\right), 171.29\left(\mathrm{C}_{\mathrm{q}}\right), 166.18\left(\mathrm{C}_{\mathrm{q}}\right), 164.93\left(\mathrm{C}_{\mathrm{q}}\right), 163.30\left(\mathrm{C}_{\mathrm{q}}\right)$, $161.91\left(\mathrm{C}_{\mathrm{q}}\right), 159.25\left(\mathrm{C}_{\mathrm{q}}\right), 157.89\left(\mathrm{C}_{\mathrm{q}}\right), 151.87\left(\mathrm{C}_{\mathrm{q}}\right), 151.52\left(\mathrm{C}_{\mathrm{q}}\right), 148.21(\mathrm{CH}), 148.05(\mathrm{CH})$, $138.30(\mathrm{CH}), 135.66(\mathrm{CH}), 135.51(\mathrm{CH}), 132.87(\mathrm{CH}), 132.73(\mathrm{CH}), 130.48(\mathrm{CH}), 130.45(\mathrm{CH})$, $128.83(\mathrm{CH}), 128.80(\mathrm{CH}), 124.95(\mathrm{CH}), 124.90(\mathrm{CH}), 124.85(\mathrm{CH}), 124.69\left(\mathrm{C}_{\mathrm{q}}\right), 121.79\left(\mathrm{C}_{\mathrm{q}}\right)$, $121.63\left(\mathrm{C}_{\mathrm{q}}\right), 119.74(\mathrm{CH}), 119.56(\mathrm{CH}), 117.15(\mathrm{CH}), 116.83(\mathrm{CH}), 116.79(\mathrm{CH}), 116.47(\mathrm{CH})$, 114.24 (CH), $113.37(\mathrm{CH}), 95.05(\mathrm{CH}), 94.84(\mathrm{CH}), 51.78\left(\mathrm{CH}_{2}\right), 51.68\left(\mathrm{CH}_{2}\right)$. ESI-MS: [M] $]^{+}$ 258. IR (neat, $\mathrm{cm}^{-1}$ ): 3184, 2986, 1629, 16191579, 1536, 1438, 1400, 1307, 1297, 1195, 775. Elemental analysis calcd (\%) for $\mathrm{C}_{14} \mathrm{H}_{11} \mathrm{FN}_{2} \mathrm{O}_{2}: \mathrm{C}, 65.11 ; \mathrm{H}, 4.29 ; \mathrm{N}, 10.85$; found: $\mathrm{C}, 65.41$; $\mathrm{H}, 4.52 ; \mathrm{N}, 11.02$.

(E)-3-((2-Fluorophenyl)(hydroxy)methylene)imidazo[1,2-a]pyridin-2(3H)-one (5). To a solution of compound $3(258 \mathrm{mg}, 1.0 \mathrm{mmol})$ in $\mathrm{CH}_{2} \mathrm{Cl}_{2}(5 \mathrm{~mL})$ was added dropwise a solution of $\mathrm{Br}_{2}(160 \mathrm{mg}, 1.0 \mathrm{mmol})$ in $\mathrm{CH}_{2} \mathrm{Cl}_{2}(3 \mathrm{~mL})$ at $0{ }^{\circ} \mathrm{C}$. The reaction mixture was warmed to room temperature and stirred further for an additional $90 \mathrm{~min}$. Then the mixture was washed with a saturated solution of $\mathrm{NaHCO}_{3}$ and the organic layer was evaporated under reduced pressure giving a solid crude that was recrystallized from $\mathrm{Et}_{2} \mathrm{O}$ to give compound 5 as a pale yellow solid (231 mg; 91\%). MP: $167-168{ }^{\circ} \mathrm{C} .{ }^{1} \mathrm{H}-\mathrm{NMR}$ $\left(250 \mathrm{MHz}, \mathrm{DMSO}_{6}\right) \delta 12.28(\mathrm{~s}, 1 \mathrm{H}, \mathrm{OH}), 9.92(\mathrm{~d}, J=7.0 \mathrm{~Hz}, 1 \mathrm{H}, \mathrm{H}-5), 7.79(\mathrm{t}, J=8.0 \mathrm{~Hz}$, 1H, H-7), 7.49-7.28 (m, 4H, H-6,8, $\left.4^{\prime}, 6^{\prime}\right), 7.25-7.10$ (m, 2H, H-3', 5$)$ ppm. ${ }^{13} \mathrm{C}$ NMR (63 MHz, DMSO-d $\left.{ }_{6}\right) \delta 175.35\left(\mathrm{C}_{\mathrm{q}}, \mathrm{C}-\alpha\right), 159.10\left(\mathrm{~d}, J=246.0 \mathrm{~Hz}, \mathrm{C}_{\mathrm{q}}, \mathrm{C}-2^{\prime}\right), 158.92\left(\mathrm{C}_{\mathrm{q}}, \mathrm{C}-3\right), 137.75$ $\left(\mathrm{C}_{\mathrm{q}}, \mathrm{C}-9\right), 134.11(\mathrm{CH}, \mathrm{C}-7), 130.90\left(\mathrm{~d}, \mathrm{~J}=8.2 \mathrm{~Hz}, \mathrm{CH}, \mathrm{C}-4^{\prime}\right), 129.70\left(\mathrm{~d}, \mathrm{~J}=4.0 \mathrm{~Hz}, \mathrm{CH}, \mathrm{C}-6^{\prime}\right)$, $129.26\left(\mathrm{~d}, J=17.1 \mathrm{~Hz}, \mathrm{C}_{\mathrm{q}}, \mathrm{C}-1^{\prime}\right), 129.05(\mathrm{CH}, \mathrm{C}-7), 124.01\left(\mathrm{~d}, J=3.2 \mathrm{~Hz}, \mathrm{CH}, \mathrm{C}-5^{\prime}\right), 116.41$ $(\mathrm{CH}, \mathrm{C}-6), 115.33\left(\mathrm{~d}, J=21.9 \mathrm{~Hz}, \mathrm{CH}, \mathrm{C}-3^{\prime}\right), 108.21(\mathrm{CH}, \mathrm{C}-8), 104.73\left(\mathrm{C}_{\mathrm{q}}, \mathrm{C}-3\right) \mathrm{ppm}$. ESI-MS: $[\mathrm{M}]^{+}$256. IR (neat, $\mathrm{cm}^{-1}$ ): 3015, 2969, 2841, 1699, 1686, 1610, 1569, 1438, 1307, 1257, 1212, 1139 , 752. Elemental analysis calcd (\%) for: $\mathrm{C}_{14} \mathrm{H}_{9} \mathrm{FN}_{2} \mathrm{O}_{2}: \mathrm{C}, 65.62 ; \mathrm{H}, 3.54 ; \mathrm{N}, 10.93$; found: C, 65.81; H, 3.82; N, 11.20. 


\section{Conclusions}

A N-2-pyridyl- $\beta$-ketoamide was shown to be a suitable precursor to the hitherto unknown 3-arylmethyleneimidazo[1,2-a]pyridin-2(3H)-one framework via a domino process comprising bromination, intramolecular nucleophilic substitution, and keto-enol tautomerism stages.

Supplementary Materials: The following are available online: copies of spectra of compounds 3 and 5, including 2D-NMR correlation experiments.

Author Contributions: Conceptualization, G.T., Á.C., M.T.R., and J.C.M.; Methodology, G.T., and Á.C.; Writing—original draft preparation, J.C.M.; Writing—review and editing, G.T., A.C., M.T.R., and J.C.M.; Supervision, M.T.R. and J.C.M.; Funding acquisition, J.C.M. All authors have read and agreed to the published version of the manuscript.

Funding: This research was funded by Ministerio de Ciencia, Innovación y Universidades (grant RTI2018-097662-B-I00), Comunidad de Madrid (postdoctoral contract to Á.C.) and Universidad Complutense (predoctoral contract to G.T.). The APC was not funded.

Institutional Review Board Statement: Not applicable.

Informed Consent Statement: Not applicable.

Data Availability Statement: Data are available from the authors, upon request.

Conflicts of Interest: The authors declare no conflict of interest.

\section{References}

1. Goel, R.; Luxami, V.; Paul, K. Imidazo[1,2-a]pyridines: Promising drug candidates for antitumor therapy. Curr. Top. Med. Chem. 2016, 16, 3590-3616. [CrossRef] [PubMed]

2. Yu, Y.; Han, Y.; Zhang, F.; Gao, Z.; Zhu, T.; Dong, S.; Ma, M. Design, synthesis, and biological evaluation of imidazo[1,2-a]pyridine derivatives as novel PI3K/mTOR dual inhibitors. J. Med. Chem. 2020, 63, 3028-3046. [CrossRef] [PubMed]

3. Foda, N.H.; Ali, S.M. Zolpidem tartrate. Profiles Drug Subst. Excip. Relat. Methodol. 2012, 37, 413-438. [PubMed]

4. Skolnick, P. Anxioselective anxiolytics: On a quest for the holy grail. Trends Pharmacol. Sci. 2012, 33, 611-620. [CrossRef] [PubMed]

5. Das, D.; Bhutia, Z.; Panjikar, P.C.; Chatterjee, A.; Banerjee, M. A simple and efficient route to 2-arylimidazo[1,2-a]pyridines and zolimidine using automated grindstone chemistry. J. Heterocycl. Chem. 2020, 57, 4099-4107. [CrossRef]

6. Mizushige, K.; Ueda, T.; Yukiiri, K.; Suzuki, H. Olprinone: A phosphodiesterase III inhibitor with positive inotropic and vasodilator effects. Cardiovasc. Drug Rev. 2006, 20, 163-174. [CrossRef] [PubMed]

7. Kumar Bagdi, A.; Santra, S.; Monir, K.; Hajra, A. Synthesis of imidazo[1,2-a]pyridines: A decade update. Chem. Commun. 2015, 51, 1555-1575. [CrossRef] [PubMed]

8. Tashrifi, Z.; Mohammadi-Khanaposhtani, M.; Larijani, B.; Mahdav, M. C3-functionalization of imidazo[1,2-a]pyridines. Eur. J. Org. Chem. 2020, 269-284. [CrossRef]

9. Hemasrilatha, S.; Sruthi, K.; Manjula, A.; Harinadha Babu, V.; Vittal Rao, B. Synthesis and anti-inflammatory activity of imidazo[1,2-a]pyridinyl/pyrazinyl benzamides and acetamides. Indian J. Chem. 2012, 51B, 981-987.

10. Heil, M.; Hoffmeister, L.; Webber, M.; Ilg, K.; Goergens, U.; Turberg, A. Preparation of Mesoionic Imidazopyridines for Use as Insecticides. WO Patent 2018192872, 25 October 2018.

11. Liu, Z.; Li, Q.X.; Song, B. Recent research progress in and perspectives of mesoionic insecticides: Nicotinic acetylcholine receptor inhibitors. J. Agric. Food Chem. 2020, 68, 11039-11053. [CrossRef] [PubMed] 